\title{
V. Characters of a few apparently undescribed Insects collected by James Gibbon, Esq., at Moreton Bay. By Edward Newman, Esq., F.L.S.
}

[Read 4th February, 1856.]

\section{Class COLEOPTERA, Linn.}

\section{Stirps ELATERINA, Newman.}

Genus Elater, Linnæus.

Sp. 1. Elater (Alaus) Gibboni, Newman.

Niger, lanugine brevi tricolori, i. e., albido, cinereo, nigro, dense vestitus, quoad elytra colore nigro vittatim disposito, elytris et prothorace medianis longitudinaliter detritis, lanugine denudatis, tunc aterrimis glaberrimis, illis 9-striatis, striis ordinatim profunde punctis: subtus, lanugine testaceo-fusco omnino dense tectus. (Corp. long. $1 \cdot 5$ unc; elytrorum lat. max. -5 unc.)

The serrated antennæ are short, scarcely half as long at the prothorax and of an opaque dingy black, the basal joints slightly tinged with rust-colour, this being due to the pile, which appears originally to have clothed every part of the insect; the head is semicircularly notched in front, its colour grey, sparingly interspersed with black and testaceous scale-like hairs; the eyes are black, naked and brilliantly glabrous : the prothorax has on its anterior margin two small teeth, which project slightly over the head ; it is densely covered dorsally with greyish white pile, except along the mesial line, where it appears to have been denuded by friction, and where the exposed dermal envelope is intensely black and brilliantly glabrous; the grey pile is interrupted on the lateral margins by five equidistant black spots, one occupying each angle and three intervening, the middle one is the largest and is somewhat quadrate; the pile of the prothorax, like that of the head, is interrupted by specks of black and testaceous: the elytra are densely clothed with pile, each has nine striæ and the interspaces are alternately slightly raised and slightly depressed; the pile on the depressed interspaces is tinged with testaceous, that on the 
elevated interspaces is whiter and is interrupted by lengthened spots of an intense velvety black. Beneath, every part of the insect is covered with a dense concolorous pile of a testaceous brown colour.

The species of the very natural division of Elater, which has received the name of Alaus, are of uniform habit and uniformly of large size : this beautiful species, the only Australian one which I have happened to meet with, is no exception, and I have been less particular in details of form and sculpture, because they present no salient differences. Mr. Gibbon found a single specimen in a saw-pit, and I have great pleasure in associating it with the name of one who has done so much for the Entomology of Australia, and who has with such liberality presented the rarities of his collection to our national Museum.

\section{Sp. 2. Elater (Dorcostoma) Jansoni, Newman.}

Obesus, depressus, subcomplanatus, fuscus, opacus, pilis sparsis brevibus adpressis pallidioribus omnino tectus; capite mediocri, in prothorace recepto, prothorace duplo angustiori; labro porrecto acuto; mandibulis exsertis porrectis, extus hirsutis, prominentibus, dente mediano valido interno armatis, apice uncinatis, acutissimis; oculis aterrimis glabris, prominulis; prothorace lato antice sinuato, lateribus dilatatis, antice subrotundatis postice subexcavatis, angulis posticis productis, dentem magnum truncatum utriusque lateris fingentibus; elytris dilatatis marginatis, costis paullulum at manifesto reflexis puncto-striatis, striis 9. (Corp. long. 1 unc.; elytrorum lab. max. $\cdot 425$ unc.)

Brown, unicolorous without gloss, beset with short scattered appressed hairs. Antennæ about equal in length to the prothorax, 11-jointed, flattened, slightly serrated; labrum somewhat trigonate, porrected, acute in front; mandibles very strong, porrected, prominent, slightly hooked and very acute at the tips, and having one large strong very acute tooth, situate about the middle of the internal margin ; prothorax broad, the longitudinal and transverse breadth nearly equal, its anterior margin excavated to receive the head, and the excavation slightly sinuated, the lateral margins dilated, anteriorly rounded, posteriorly somewhat excavated, each posterior angle produced into a large blunt tooth; elytra broad, somewhat depressed, the costal margin dilated and somewhat reflexed, the dilation originating below the shoulder; the disk impressed with nine well-marked punctate striæ, the interstices 
somewhat convex, the punctures of striæ regular, moderately deep, very distinct; legs short; prosternum verrucate; mouth, antennæ and legs somewhat rufo-piceous, the whole under surface clothed more thickly than the upper with short pale pile.

A single specimen of this interesting insect, captured by $\mathrm{Mr}$. Gibbon, is in that gentleman's collection.

I have named it in honour of our learned Curator, Mr. Janson, than whom no one has studied the Elaterina with more profound science or acuteness. The species is particularly interesting, as subserving the view entertained by the illustrious Kirby of connecting the Elaterina with certain Cebrionida, more particularly with the Anelastes Drurii of Kirby, described and figured in the twelfth volume of the Linnæan Transactions.--Linn. Trans. xii. 285.

\section{Stirps CERAMBYCINA, Newman.}

\section{Genus Stenoderus.}

\section{Sp. 1. Stenoderus quietus, Newman.}

Caput ac prothorax testacea, glaberrima, oculis antennisque nigris; scutello nigro, quoad discum depresso opaco, quoad marginem posticum simicirculariter elevato; elytris latis testaceis opacis nullo modo signatis, carinis elevatis 4 concoloribus ; prosterno procoxisque late testaceis, metasterno nigro; mesocoxis testaceis, mesofemoribus sordide testaceis; tibiis tarsisque omnibus, metapedibusque omnino nigris ; abdomine chalybeo-nigro, lumine mutato iridescente. (Corp. long. .5 unc.; elytrorum lat. $\cdot 15$ unc.)

Head and prothorax above and below bright testaceous, very glabrous : eyes, antennæ and scutellum black; elytra testaceous, opaque, broader than is usual in the genus; each has four sharp well-defined parallel ridges extending throughout its entire length; the fore and middle coxæ are testaceous; the fore and middle femora testaceous, but more dusky; all the tibiæ and tarsi and the whole of the hind legs are black, devoid of gloss; the metasternum and abdomen are black and shining, and exhibit iridescent colours when moved in the light.

Hab. Moreton Bay. A single specimen was collected by Mr. Gibbon, together with abundance of allied species, as Pentacosmia atricilla, Stenoderus ostricilla, \&c. 


\title{
Class LEPIDOPTERA, Linn.
}

\author{
Stirps SPHINGINA, Newman.
}

Genus Deilephila, Ochsenheimer.

\section{Sp. 1. Deilephila Dalii, Newman.}

Alis anticis fuscis, colore transversim undato; lunula mediand nonnunquam puncto quoque proximo niveis; posticis ferrugineis nullo modo signatis; abdomine pallide fusco incisuris saturatioribus. (Corp. long. 1.6 unc.; alarum dilat. 3 unc.)

The fore wings are brown, waved transversely with a somewhat darker hue; near the centre of the disk of the wing is a snow-white lunule, and almost close to the anterior limb of this, but slightly nearer the apex of the wing, and also nearer its costa, is a spot of the same colour; these markings, very conspicuous and ornamental in the greater number of specimens, are subject to much variation, both as to magnitude and distinctness, the white in some instances is tinged more or less with the prevailing colour of the wing, and occasionally is altogether obliterated; hind wings altogether ferruginous, with paler cilia. Head, thoracic segments and abdomen brown, the last decidedly the palest, but each segment has on each side a dark patch at the base. Beneath, the clothing of the face and palpi is whitish, the sternum and abdomen brownish grey; the fore wings are dingy brown, with two narrow transverse and somewhat indistinct waved discoidal lines.

A common species at Moreton Bay. Mr. Gibbon took it in some abundance. I have named it in honour of Mr. Dale, of Glanville's Wootton, one of our very best practical Entomologists.

Genus Macroglossa, Ochsenheimer.

Sp. 1. Macroglossa Nox, Newman.

Fusco-nigra; alis posticis nigerrimis, margine costali late albido ; abdominis segmentis lateraliter nigro niveoque ornatis. (Corp. long. 1.5 unc.; alarum dilat. 2.2 unc.)

Above, the palpi, head, thoracic segments and fore wings are dark brown approaching to black, the fore wings exhibiting traces of transverse fasciæ of a darker hue, and all these also exhibit 
slight metallic reflections of green and blue; the hind wings are intensely black as regards all that portion exposed when the wings are extended at right angles with the body, but in the folded portion near the abdomen are two pale clouds, and the entire costal margin covered by the fore wing is white; the abdomen is nigroæneous along the middle, the æneous tint being due to a rather copious sprinkling of glittering golden scales among the black; three segments near the base have, on each side, a basal black spot and a marginal white one; the anal brush is black, the tips of the scales paler. Beneath, the palpi, face and sternum are whitish grey, the dark colour of the epicranium and the white of the under side distinctly and abruptly separated from each other, the dark colour descending obliquely to the lower margin of the eye; the abdomen blackish, approaching to grey towards the anus, but the anal brush quite black; the basal segments are marked with white in the centre, and four of the segments have a very conspicuous snow-white spot on each lateral margin; the fore wings are black, inclining to grey at the base, and the hind wings are black exteriorly, but grey towards the base, and especially in the folded portion near the abdomen.

This appears to be a common insect at Moreton Bay. Mr. Gibbon brought home many specimens, some of which are presented to the British Museum.

\section{Stirps BOMBYCINA, Newman.}

Genus CAstulo, Walker.

\section{Sp. 1. Castulo Doubledayi, Newman.}

Antennis bipectinatis nigris, ramulis fuscescentibus; epicranio oculisque nigris; labipalpis porrectis late miniatis; prothorace miniato; mesothorace atque patagiis nigricantibus; abdomine rufescenti; alis anticis nigricantibus, costa rufescenti, macula basali rufescente vagâ, macula prope angulum analem albida; posticis flavis, margine postico late nigricante. (Alarum dilat. $1 \cdot 2$ unc.)

Male.-Labial palpi bright red, somewhat acuminate, ascending and porrected; crown of the head and eyes black; antennæ rather less than half as long as the fore wings, strongly bipectinated, the shaft black, the pectinations pale brown; prothorax bright red; mesothorax and tippets nearly black; abdomen reddish-orange coloured ; fore wings-above-black, sprinkled with orange scales, 
but these, although numerous, are so minute as scarcely to alter the general black colour of the wing; costa red for about half its length,- - this colour commences within a short distance of the base, and extends beyond the middle; at the basal angle of the hinder margin is a reddish spot, and above this, between it and the costa, are two very small spots of the same colour,- on the hinder margin also, and near its anal angle, is a cream-coloured blotch, various both in size and shape; hind wings bright orange, with a broad black border, which ceases just before the anal angle; fore wings (beneath) blackish-brown, with the costa red, and a yellowish suffused blotch near the anal angle and extending thence along the margin to the base; hind wings reddish-orange, with a central black lunule and a broad black border, this diminishes towards the anal angle, before reaching which it ceases entirely,the extreme margin of the wing is paler, and the cilia again dark; the under side of the head, thoracic segments and the coxæ are bright red; femora reddish-black in front, tibiæ blackish mingled with red; fore and middle tarsi blackish, hind tarsi golden yellow; fore tibiæ unarmed, middle tibiæ with two strong apical spines, hind tibiæ with four strong spines-two median, two apical; abdomen (beneath) red, with a black vitta along the middle, and a row of black dots along each side; the three segments preceding the anus are slightly dilated laterally, and each furnished with a lateral tuft or brush somewhat as in Macroglossa.

This species is certainly allied to others which Mr. Walker has placed in his new genus Castulo, but is quite distinct from any he has described. Setina irrorella and Gnophria rubicollis are its nearest allies in the British Fauna. I have named it after my friend Henry Doubleday, who is, nemine contradicente, the prince of British Lepidopterists. Two specimens only were taken.

\section{Class DIPTERA, Linn.}

\section{Stirps TABANINA, Newman.}

Genus Pangonia, Fabricius.

Sp. 1. Pangonia Walkeri, Newman.

Testacea, nitida; scutello, sterno ventieque aterrimis; alis nitidissimis hyalinis, nebula apicali fusca; pedibus basi fuscis, apice tibiis tarsisque testaceis. (Corp. long. 75 unc.; alarum dilat. $\cdot 85$ unc.)

Testaceous above and very shining, yet clothed in patches with fulvo-testaceous pubescence; the rostrum is not longer than the 
mesothorax, the eyes dark brown, the head clothed below with hoary pubescence; mesonotum testaceous, brilliantly glabrous; scutellum black, glabrous; sternum black, but clothed with a hoary fulvous pubescence; abdomen fulvous above, with a median, not very distinct, blackish marking extending from the scutellum to the third segment, black beneath, with the exception of a pale yellowish band immediately behind the hind legs, and this is interrupted by three black obscurely defined markings, one of them central, the others lateral; coxæ and nearly the whole of the femora dark brown, approaching to black; tibiæ and tarsi testaceous.

Hab. Moreton Bay, North Australia; a single specimen was taken by Mr. Gibbon, and is in that gentleman's collection. The species of Pangonia is dedicated to Mr. Walker, whose labours in the Diptera are familiar to all Entomologists, and to whom I am indebted for pointing out the novelties in the Lepidoptera and Diptera in this collection.

\section{Stirps ASILINA, Newman.}

Genus Dasypogon, Meigen.

\section{Sp. 1. Dasypogon Grantii, Newman.}

Niger, lanugine brevissimo aureo passim vestitus; alis opacis, late fulvis; pedibus nigris; femoribus apice, tibiis basi, laele testaceis. (Corp. long. 85 unc.; alarum dilat. 1 unc.)

Black, clothed in patches with a very short golden pile; face clothed with brilliant golden pile; rostrum and antennæ black; wings opaque, deep rich fulvous, the colour deeper in the vicinity of the rays, which are concolorous, paler in the centres of the cells ; femora black at base, testaceous at apex ; tibiæ testaceous at base, black at apex; tarsi entirely black, each joint emitting strong black spines; claws very strong and black, pulvilli pale yellow.

Hab. Moreton Bay, North Australia, where a single specimen was taken by Mr. Gibbon, and is in that gentleman's collection. This species is dedicated to Mr. Frederick Grant, a most diligent collector of British Diptera. 


\section{$2 \mathrm{BHL}$ Biodiversity Heritage Library}

Newman, Edward. 1857. "V. Characters of a few apparently undescribed Insects collected by James Gibbon, Esq., at Moreton Bay." Transactions of the Entomological Society of London 9, 51-57.

https://doi.org/10.1111/j.1365-2311.1857.tb01811.x.

View This Item Online: https://www.biodiversitylibrary.org/item/51009

DOI: https://doi.org/10.1111/j.1365-2311.1857.tb01811.x

Permalink: https://www.biodiversitylibrary.org/partpdf/38255

\section{Holding Institution}

Smithsonian Libraries

\section{Sponsored by}

Smithsonian

\section{Copyright \& Reuse}

Copyright Status: Public domain. The BHL considers that this work is no longer under copyright protection.

This document was created from content at the Biodiversity Heritage Library, the world's largest open access digital library for biodiversity literature and archives. Visit BHL at https://www.biodiversitylibrary.org. 